\title{
South African Food Allergy Working Group (SAFAWG) authors of the South African food allergy consensus document 2014
}

M E Levin, MB ChB, FCPaed (SA), Dip Allergology (SA), MMed (Paeds), PhD, EAACI allergy exam (UEMS), FAAAAI, FACAACI

Division of Allergy, Department of Paediatrics and Child Health, Faculty of Health Sciences, University of Cape Town and Red Cross War Memorial Children's Hospital, Cape Town, South Africa

Research support from Mylan International, SA Medical Research Council, Nestlé, Thermo Fisher, Aspen Pharma, Cipla, Astellas, MSD, AstraZeneca, Pharma Dynamics, Nutricia, Beiersdorf. Conference attendance from Thermo Fisher. Mylan advisory board. Speaker for Mylan, Beiersdorf, Nutricia, Nycomed, Johnson \& Johnson. Advisor for Pharma Dynamics, Global Alliance for Improved Nutrition. Member of National Asthma Education Programme (NAEP), Allergy Society of South Africa (ALLSA) Executive Committee, SA Allergic Rhinitis Working Group

C L Gray, MB ChB, FRCPCH (UK), MSc (ClinPharm), Dip Allergy, DipPaedNutrician (UK)

Private Practice, Vincent Pallotti Hospital, Pinelands, Cape Town, South Africa

Member of ALLSA Executive Committee. Speaker for Pfizer, Labspec, Nutricia

E Goddard, MB ChB, MSc (Med Biochem), PhD, MMed (Paed)

Division of Paediatric Gastroenterology, Department of Paediatrics and Child Health, Faculty of Health Sciences, University of Cape Town and Red Cross War Memorial Children's Hospital, Cape Town, South Africa

S Karabus, MB ChB, FCPaed (SA), MRCPCH (UK), DCH, Dip Allergology

Private Practice, Christiaan Barnard Memorial Hospital, Cape Town, and Division of Allergy, Department of Paediatrics and Child Health, Faculty of Health Sciences, University of Cape Town and Red Cross War Memorial Children's Hospital, Cape Town, South Africa

Member of ALLSA Executive Committee

M Kriel, MB ChB, FCPaed (SA), Dip Allergology (SA)

Private Practice, Alberton, Johannesburg, South Africa

A C Lang, BSc Diet, Post Grad Dip Diet

Wits Donald Gordon Medical Centre, Johannesburg, South Africa

A I Manjra, MB ChB, FCP (SA) Paeds, Dip Allergology (SA), FAAAAI, MClinPharm

Private Practice, Westville, Durban, South Africa

Member of ALLSA Executive Committee

S M Risenga, BSc, MB ChB, MMed (Paed), DCH, Dip Allergology (SA), Cert Pulmonology (SA) Paed

Department of Pulmonology and Allergy, Faculty of Health Sciences, Polokwane Campus, University of Limpopo, Polokwane, South Africa

Member of ALLSA Executive Committee, South African Medical Association (SAMA) Branch Committee. Speakers bureaux: SAMA, Nestlé, GSK

A J Terblanche, MB ChB, MMed (Paed), FCP (SA), Dip Allergology (SA), Cert Gastroenterology (Paed) SA

Department of Paediatrics, Faculty of Health Sciences, University of Pretoria and Steve Biko Academic Hospital, Pretoria, South Africa

D A van der Spuy, BSc Diet, Post-grad Hosp Dipl, MNutr

Private Practice, Cape Town, South Africa

Nutrition Congress registration 2014 from Nutricia

S Afr Med J 2015;105(1). DOI:10.7196/SAMJ.9201 